\title{
Three decades after Penrose ${ }^{\dagger}$
}

\author{
W. I. FRASER
}

The best word for the transformation of learning disability practice in the past 30 years is 'enlightenment'. This transformation in knowledge, skills and attitudes has mirrored, for the lives of people with handicaps, the changes in society which occurred in the last decades of the 18th century (the Enlightenment).

This issue of the British Journal of Psychiatry contains six papers that reflect topics which would not have exercised specialists very much 30 years ago, but which are now at the centre of the field: molecular genetics, the pervasive developmental disorders, psychotherapy for people with learning disabilities, secondary health delivery in the post-institutional era, the impact of ageing, and approaches to psychotropic drug reduction.

Attitudes towards learning disability in the 1990s would not have been recognised 30 years ago. The 18th-century Enlightenment placed emphasis on "shared humanity, a duty to improve the lives of others" (Clegg, 1998). This attitude only started to reach most people with learning disabilities in the last three decades of the 20th century. Until the publication of Better Services for the Mentally Handicapped (Department of Health and Social Security, 1971), people with learning disability did not generally seem worth it.

It is almost 30 years since Penrose died. Strengths developed since then include theoretically sound classifications built on multivariate statistics, more theoretically sound clinical inventories and questionnaires, and, most vividly, genetic technology, exemplified by the recent identification of the gene responsible for Rett syndrome (Amir et al, 1999). Muir's (2000, this issue) paper is rich in new knowledge and its practical consequences, such as the new light cast on the concept of pfropfschizophrenia (Doody et al, 1998).

\footnotetext{
†See pp. 12-46, this issue.
}

Berney's review of autism (2000, this issue) points out that it is more prevalent the more severe the degree of learning disability, and raises three questions. First, how much does autism contribute to learning disability? Second and conversely, can severe learning disability be distinguishable from autism? Third, are there some medical disorders which make learning disability particularly likely to produce autism?

In 1970, the settlement of people from institutions in the community had hardly started. In England and Wales (much less so in Europe), the process of de-institutionalisation is now largely established. The record linkage study reported here by Morgan et al (2000, this issue) shows how the health care uptake of people with learning disabilities is different from that of the general population and how the presence of a learning disability hospital affects health provision, and gives us some indication of psychiatric hospital activity for those with learning disability in the postinstitutional era.

The radically improved survival rates for individuals with learning disability in Europe have resulted in the realisation of the impact that ageing will have on learning disability services. In 1929 the average life expectancy of an individual with Down's syndrome was nine years; by 1969 various surveys suggested that it was 59 years. It is still increasing, albeit less strikingly. The fact that people with learning disabilities are living longer has been recognised by the International Association for the Scientific Study of Intellectual Disability via the creation of a very active special interest research group and by the European Commission's fifth biomedical research framework. Holland's (2000, this issue) review emphasises these developing agerelated problems and how diagnostic overshadowing obscures pathology. Here again we have evidence on which to base services.

In a recent Cochrane Commemorative Lecture in Cardiff, Chalmers expressed the ambition that decisions about health be informed by reliable and relevant evidence. Brylewski \& Duggan (1998) and Duggan \& Brylewski (1999), in two systematic reviews, have pointed out that there is little basis in the literature for the prescription of antipsychotic medication to people with learning disabilities, even those with schizophrenia. Hollins \& Sinason (2000, this issue) admit that they cannot conduct a systematic review of the use of psychological therapies in people with learning disabilities because there is insufficient published literature. They report that there are few outcome studies.

Chalmers (1997) pointed out that new developments in health care are not necessarily advances. This view is vividly illustrated in the use of psychotropic drugs for the management of behaviour problems in those with learning disability. Rights issues, menacing litigation and the clarification of challenging behaviour have kindled interest from the National Health Service Research and Development Directorate (and the Health Technology Assessment Commissioners) in a search for evidence of the effectiveness of behavioural and psychopharmacological measures and have led to commissioned antipsychotic drug reduction studies, as described by Ahmed et al (2000, this issue).

Chalmers (1998) has also made a plea for researchers to involve the public more. This ought to include people with learning disability. This topic has recently been addressed by the Royal College of Psychiatrists working party that is preparing guidelines for ethical committees on psychiatric research. Research in learning disability is made more difficult by people with learning disability often being automatically excluded from participation. They have been regarded as not having the moral development to enable them to contribute for altruistic reasons to non-therapeutic research. This lack of opportunity to take part is now at last regarded as disenfranchising. Equally importantly, such an attitude detracts from the representativeness of mental health research. Approaches to determining capability have recently been reviewed by Wong et al (1999). A blanket "dependent-incapable-status" approach is gradually being displaced by a functional approach (Hoggett, 1994; Arscott, 1997) which focuses on the person's relative abilities and the extent to which these abilities meet, with careful additional explanation, the demands of a particular decision-making 
task. It is to be hoped that people with learning disabilities will in future have more chance to share the burdens and benefits of ordinary people (Edwards, 1997). The following six papers demonstrate the enlightenment of the past 30 years. I am sure that Penrose would be pleased.

\section{REFERENCES}

Ahmed, Z., Fraser, W., Kerr, M. P., et al (2000)

Reducing antipsychotic medication in people with a learning disability. British Journal of Psychiatry, 176, 4246

Amir, R. E., Van den Veyver, I. B. \& Wan, M. (1999) Rett syndrome is caused by mutations in $\mathrm{X}$-linked MECP2, encoding methyl-CpG-binding protein 2. Nature Genetics, 23, 185-188.

Arscott, K. (1997) Assessing the capacity of people with learning disabilities to make decisions about treatment. Tizard Learning Disability Review, 2, 17-28.

Berney, T. P. (2000) Autism - an evolving concept. British Journal of Psychiatry, I76, 20-25.

Brylewski, J. \& Duggan, L. (1998) Antipsychotic medication for challenging behaviour in people with learning disability. The Cochrane Library, Issue I, pp. I-13. Oxford: Update Software.

Professor W. I. FRASER, MD, Welsh Centre for Learning Disabilities, Meridian Court, North Road, Cardiff CFI4 3BL

(First received 12 July 1999, accepted 15 July 1999)

Chalmers, I. (1997) What is the prior probability of a proposed new treatment being superior to established treatments? (letter). British Medical Journal, 314, 74.

_ (1998) Unbiased, relevant and reliable assessments in health care. British Medical Journal, 317, I167-1168.

Clegg, J. (1998) Critical Issues in Clinical Practice. London: Sage.

Department of Health and Social Security (1971) Better Services for the Mentally Handicapped. London: $\mathrm{HMSO}$

Doody, G. A., Johnstone, E. C., Sanderson, T. L., et a (1998) 'Pfropfschizophrenie' revisited. Schizophrenia in people with mild learning disability. British Journal of Psychiatry, 173, 145-153.

Duggan, L. \& Brylewski, J. (1999) Effectiveness of antipsychotic medication in people with intellectual disability and schizophrenia. A systematic view. Journal of Intellectual Disability Research, 43, 94-105.

Edwards, S. D. (1997) The moral status of intellectually disabled individuals. Journal of Medical Philosophy, 22. 129-142.
Hoggett, B. (1994) Mentally incapacitated adults and decision making. The Law Commission's project. In Decision-Making and Problems of Incompetence (ed A. Grubb), pp. 27-40. Chichester: John Wiley \& Sons.

Holland, A. J. (2000) Ageing and learning disability British Journal of Psychiatry, 176, 26-31.

Hollins, S. \& Sinason, V. (2000) Psychotherapy, learning disabilities and trauma: new perspectives. British Journal of Psychiatry, 176, 32-36.

Morgan, C. L., Ahmed, Z. \& Kerr, M. P. (2000) Health care provision for people with a learning disability. Record-linkage study of epidemiology and factors contributing to hospital care uptake. British Journal of Psychiatry, 176, 37-4I.

Muir, W. J. (2000) Genetics advances and learning disability. British Journal of Psychiatry, 176, 12-19.

Wong, J. G., Clare, I. C. H., Gunn, M. J., et al (1999) The capacity of people with a mental disability to make a health care decision. Psychological Medicine, 29, 437442 . 